\title{
The effect of positive psychological capital and organizational climate on service quality: The mediation role of work engagement of hotel service employees in Ratchaburi province
}

\author{
Jetlaksana Seneewong Na Ayutthaya ${ }^{1,{ }^{*}}$, Sudarat Tuntivivat ${ }^{2}$, Ujsara Prasertsin ${ }^{3}$ \\ 1, 2, 3 Srinakharinwirot University, Bangkok, Thailand
}

\section{Keywords:}

Positive psychological capital Organizational climate

Work engagement

Service quality

Received: 28 April 2016

Accepted: 18 June 2016

Published: 12 August 2016

\begin{abstract}
Low work engagement has become a major challenge among hotel service employees in Thailand. This research explores the effect of positive psychological capital and organizational climate on service quality: the mediation role of work engagement of hotel service employees in Ratchaburi province. The mixed method research is employed through quantitative and qualitative approach to answer three research questions comprehensively. First, the quantitative method uses questionnaires to collect the data from 217 hotel service employees in Ratchaburi province. Then, qualitative method conducts focus group interview with 10 hotel service employees who have received an excellent service quality award in the past 2 years. The qualitative finding indicates that work engagement significantly influences service quality of hotel service employees in Ratchaburi province. Therefore, this study recommends observing further the work engagement of employees from different job functions in order to improve service quality for entire organization.
\end{abstract}

(C) 2016 The Author(s). Published by TAF Publishing.

\section{INTRODUCTION}

In today's competitive global markets, the hotel industries seem to face various challenges. Particularly, the small and medium size hotels are required to provide excellent service of global standard in order to attract and obtain customers. Hotel service employees play an important role in providing excellent service and ensuring customers' satisfaction before, during and after stay at the hotel (Bitner, 1992).

\footnotetext{
*Corresponding author: Jetlaksana Seneewong Na Ayutthaya
}

E-mail: jetlaksana@gmail.com
Therefore, it is vital for hotel management to put emphasis on work behavior and job performance of hotel service employees, value genius work engagement and achieve quality service in order to obtain a sustainable successful business (Snyder \& Lopez, 2002:761). The hotel businesses in Ratchaburi also have been impacted in terms of service quality because there are too many accommodations in services in Ratchaburi such as hotels, resorts, guesthouses and hostels. Thus, the entrepreneurs need to create the strategic plan to attract the customers. In addition, the Ratchaburi province establishes a strategic plan to draw the tourists to visit Ratchaburi by setting 
goals to corporate with the tourism company and accommodation for increasing the tourists coming to visit Ratchaburi province (Boonmak, Peeranut \& Suchart, 2013:20). Furthermore, hotel businesses in Ratchaburi province have to manage the service quality to be the best that can make customers satisfied otherwise the hotel business will lose the customers. That is the reason why the local entrepreneurs have to focus on service quality in their business. The service quality can be measured by the customer's satisfaction and by comparing the past experience of service quality (Cronin Jr \& Tylor, 1992:159). Service quality can be affected by 2 factors which are personal factor and environmental factor. This can be explained by the concept of Albanese (1981) the managing towards accountability for performance. This notion illustrated the personal performance from the personal factor and environmental factor. The first factor is personal factor that consists of ability to contribute to success, recognition of the role and attitudes, values, and motivation. The second factor is environmental factor that consists of environment in work place, the relationships with colleagues, and work description. These two factors show that the personal performance has to consist of both internal and external factors including the relationship between factors within the person and external factors outside the person.

Many previous researchers examined the service quality of hotel customers in terms of assessing perceptions of service quality in service, production and consumption that consist of five dimensions which are reliability, assurance, tangibility, empathy and responsiveness. However, there is no research that has explored the effect of positive psychological capital and organization climate on service quality. Therefore, this study aims to investigate the effect of positive psychological capital and organization climate on service quality: the mediation role of work engagement of hotel service employees. This research begins with literature review.

\section{Objectives}

1. To study the effect of positive psychological capital and organizational climate on service quality: the mediation role of work engagement of hotel service employees in Ratchaburi province.

2. To explore the in-depth reason of relationship between the factors and solution to develop the work engagement of hotel service employees.

\section{LITERATURE REVIEW}

Positive psychological capital is defined as the positive and developmental state of an individual that consists of 4 dimensions which are hope, self-efficacy, optimism and resilience (Luthans, Youssef \& Voloi, 2007). Positive psychological capital and organization climate are necessary for human resources in order to achieve stable organizational growth (Litwin \& Stringer, 1968). Jung \& Yoon (2015) studied the impact of employees' positive psychological capital on job satisfaction and organizational citizenship behaviors in the hotel. This study was administered to 324 deluxe hotel employees using a selfadministered questionnaire. The research showed that employees' hope and optimism among positive psychological capital have a significant effect on their job satisfaction; their hope and resilience affect organizational citizenship behaviors. Employees' satisfaction was positively associated with their organizational citizenship behaviors. It was verified that positive psychological capital was an important performance factor that could improve hotel employees' attitudes and organization's effectiveness. Employees with high positive psychological capital were high in satisfaction with job, positively helped coworkers or superiors, and had high possibility of doing devotional action for organization.

Accordingly, there will be a need of forming favorable working atmosphere so that employees can perform job with positive psychology, and of seeking diverse support programs such as counseling program or leisure activity. Karatepe \& Karadas (2015) study was "Do psychological capital and work engagement foster frontline employees' satisfaction? A study in the hotel industry". The research results suggest that optimism appears to be the best indicator of psychological capital, followed by resilience, self-efficacy and hope. Employees with high psychological capital are engaged in their work at elevated levels. Employees high in psychological capital are more satisfied with their job, career and life. The results reported in this study further suggest that psychological capital boosts work engagement that in turn leads to job, career and life satisfaction. Organizational climate is defined as the set of work environment, perceived directly or indirectly by the employees, that is assumed to be a major force in influencing employee behavior. Organizational climate is the support that an employee receives from his/her coworkers, other departments and their supervisors which helps them with their job demands (Roderic, 2007; Dubrin, 1984). Taştan \& Güçel (2014) study examines perceived 
organizational climate and organizational identification as potential antecedents of employees' entrepreneurial behaviors. In particular, the study suggests positive relationships between perceived organizational climate components-structural support and recognition- and entrepreneurial behaviors construct. In addition, employees' organizational identification is suggested to have a mediating role in the relationship between organizational climate and entrepreneurial behaviors. The survey of this study is performed among employees working in high performing and innovative firms operating in White Good Manufacturing, Food and Drink, Telecommunication, and Textile industries in Turkey. Analyses results revealed that both dimensions of organizational climate (structural support and organizational recognition) are significantly and positively related to entrepreneurial behaviors and perceived organizational identification mediates the effects of the organizational climate on the entrepreneurial behaviors construct.

Work Engagement is defined as connecting of organization member's selves to their work roles that consist of 3 dimensions which are vigor, absorption, and dedication. Employees who are engaged with their work are energetic and dedicated to their work (Kahn, 1990; Saks, 2006). Karatepe \& Demir (2014) study was "Linking core self-evaluations and work engagement to work-family facilitation: A study in the hotel industry". This article aims to develop and test a research model that investigates work engagement as a mediator of the effect of core selfevaluations on work-family facilitation and family-work facilitation. The results suggest that work engagement functions as a full mediator of the impact of core selfevaluations on work-family facilitation and family-work facilitation.

Specifically, frontline employees with positive core selfevaluations are highly engaged in their work, and therefore, are capable of integrating their work (family) and family (work) roles successfully. Ling Suan \& Mohd Nasurdin (2016) study was "Supervisor support and work engagement of hotel employees in Malaysia: Is it different for men and women?"This study aims to examine the impact of supervisor support and to assess the moderating role of gender on employee work engagement in the context of the Malaysian hospitality industry.

The findings indicated that supervisor support positively influences work engagement and that this positive relationship was stronger for male employees than female employees. Service quality is defined as perceptions of service quality in service, production and consumption that consist of five dimensions which are reliability, assurance, tangibility, empathy and responsiveness (Berry, Zeithaml \& Parasuraman, 1985). Minh, Ha, Anh \& Matsui (2015:1) studied service quality and customer satisfaction: a case study of hotel industry in Vietnam. This study is to empirically examine the relationship between service quality and customer satisfaction in Vietnamese hotels. Survey questionnaire was constructed with 23 service quality items. Data were collected from 432 guests of 33 three-star hotels in Vietnam in 2013 Analysis results indicate that reliability, responsiveness, assurance and empathy significantly impact on the customer satisfaction. The study implies that service quality plays an important role as a driver for higher customer satisfaction level in hotel service. Managers should focus on Empathy, Reliability, Responsiveness, and Assurance to achieve high degree of customer satisfaction which leads to customer loyalty and business profit. Heung \& Wong, (1997:1) studied Hotel service quality in Hong Kong: A study of tourists' expectations.

The study aims to measure travelers' capitations of service quality for Hong Kong hotels. A total of 200 travelers were surveyed. It was found that travelers, whether on business or pleasure, have high expectations of service quality in Hong Kong hotels. However, there are differences in the various dimensions. 'Responsiveness' and 'Empathy' are more important to business travelers than leisure travelers. In order to compete successfully in the hotel industry, management must know what their customers expect and provide services to meet their expectations. Since there are differences in the levels of service expectation between business and leisure travelers, management should address those differences accordingly.

\section{CONCEPTUAL FRAMEWORK}

\section{Phase 1}

Quantitative Research: To study the effect of positive psychological capital and organizational climate on service quality: the mediation role of work engagement of hotel service employees in Ratchuburi province.

\section{Phase 2}

Qualitative Research: To explore the in-depth reason of relationship between the factors and solution to develop the work engagement of hotel service employees. 


\section{METHODOLOGY}

\section{Participants}

This research is mixed method research between the quantitative method and qualitative method. For the Quantitative method, the population of hotel service employees in Ratchaburi was 239 people. The researcher gave the questionnaires to 5 hotels which are the medium hotels to the large hotels in Ratchaburi. The researcher collected 217 questionnaires that were 90.80 percent. There searcher qualitatively conducted focus group interview with 10 hotel service employees who have received an excellent service quality award in the past 2 years. The focus group interview took 2.5 hour.

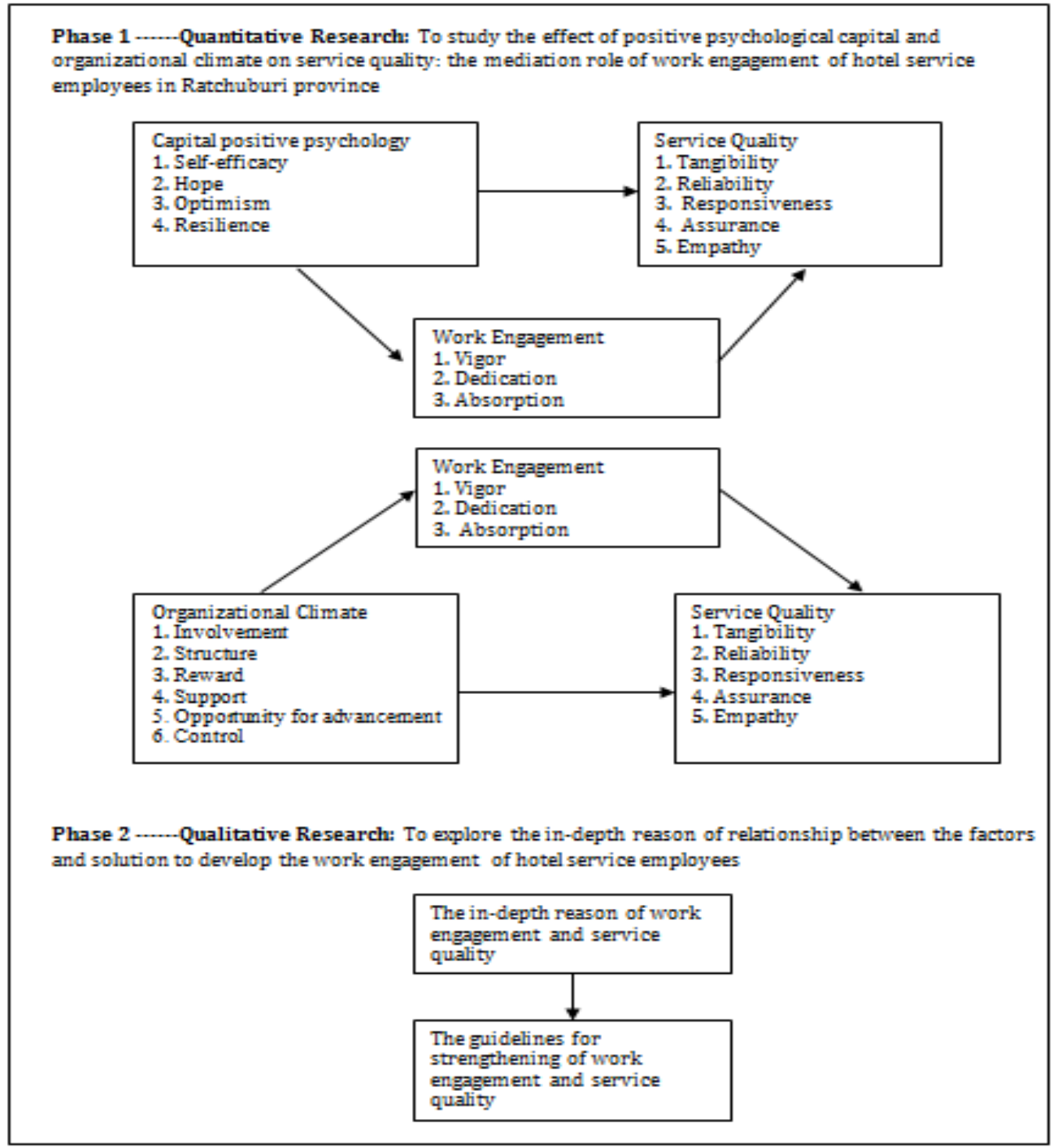

FIGURE 1. Conceptual framework

\section{Instruments}

All data were collected through questionnaires that were divided into 5 parts: 1) Personal information. 2) Positive psychological capital (Luthans et al., 2007) Organizational climate (Dubrin, 1984) 4) Work engagement (Watchara)
Service Quality (Berry et al., 1985). The researcher tried out the questionnaires with 30 hotel service employees in Ayutthaya province with the reliability at .60 .The details are as below: 
TABLE 1. The reliability of capital positive psychology

\begin{tabular}{lc}
\hline \hline \multicolumn{1}{c}{ Capital positive psychology } & Reliability \\
\hline Self-efficacy & .84 \\
Hope & .77 \\
Optimism & .88 \\
Resilience & .81 \\
\hline \hline
\end{tabular}

TABLE 2. The reliability of organizational climate

\begin{tabular}{lc}
\hline \hline \multicolumn{1}{c}{ Organizational climate } & Reliability \\
\hline Involvement & .60 \\
Structure & .71 \\
Reward & .67 \\
Support & .86 \\
Opportunity for advancement & .76 \\
Control & .77 \\
\hline \hline
\end{tabular}

TABLE 3. The reliability of work engagement

\begin{tabular}{lc}
\hline \hline \multicolumn{1}{c}{ Work engagement } & Reliability \\
\hline Vigor & .88 \\
Dedication & .81 \\
Absorption & .92 \\
\hline \hline
\end{tabular}

TABLE 4. The reliability of service quality

\begin{tabular}{lc}
\hline \hline \multicolumn{1}{c}{ Service quality } & Reliability \\
\hline Tangibility & .92 \\
Reliability & .91 \\
Responsiveness & .91 \\
Empathy & .93 \\
\hline \hline
\end{tabular}

So, some questions have to be deleted. Finally, the questionnaires consisted of84 questions. Then, researcher sent the questionnaires to the personnel department of each hotel in Ratchaburi by starting at January 2009 until February 2009. The total questionnaires that had been sent to each hotel were 239 questionnaires but 217 questionnaires were collected. Next, researcher chose participants who were 10 hotel service employees who had received an excellent service quality award in the past 2 years to come to focus group. The focus group discussion took 2.5 hours to finish. The qualitative data were collected through focus group which included opening questions, introduction questions and key questions. Opening questions were the general questions to make a relationship with participants and build comfort zone with them. Researcher regarded this as the most important part for collecting data and for making participant gain trust in the interviewer.

\section{Content Analysis}

Researcher analyzed content from questionnaires and focus group discussion. From the questionnaires, researcher analyzed the content by using SPSS program to find the Frequency, Mean and percentage. And for qualitative research, researcher conducted focus group interview with 10 hotel service employees who had received an excellent service quality award in the past 2 years. It was to find indicated work engagement that significantly influences service quality of hotel service employees in Ratchaburi province.

\section{RESULTS}

\section{Quantitative Research}

This research found that among the hotel service employees, most of them were females at 68.2 percent and males were at 31.8 percent. And the employee sunders 20 years were 10.1 but those with age more than 30 years were 35 percent. Most of hotel service employees were single equal to 57.1 percent and those married were28.1 percent. The experience of hotel service employees was between 1-3 years at 40.1 percent and those having experience of more than 5 years were at 24.4 percent. The findings revealed that the hotel service employees have high level of factors at positive psychological capital and work engagement on service quality except the moderate level of organizational climate. All the details are as below: Table 4 shows that the positive psychological capital was at high level and mean at 3.50. The 3 dimensions consist of optimism, hope and resilience that were at high level and mean were $3.63,3.52$ and 3.44 respectively. Only 1 dimension was self-efficacy that was at moderate level with mean at 3.40 .

TABLE 5. Mean and standard deviation of positive psychological capital

\begin{tabular}{lccl}
\hline $\begin{array}{l}\text { Positive psychological } \\
\text { capital }\end{array}$ & M & S.D & Level \\
\hline Self-efficacy & 3.40 & 1.02 & Moderate \\
Hope & 3.52 & 1.05 & High \\
Optimism & 3.63 & 1.03 & High \\
Resilience & 3.44 & 1.03 & High \\
Total & 3.50 & 1.03 & High \\
\hline \hline
\end{tabular}


TABLE 6. Mean and standard deviation of organizational climate

\begin{tabular}{llll}
\hline \hline $\begin{array}{l}\text { Organizational } \\
\text { climate }\end{array}$ & $\mathbf{M}$ & S.D. & Level \\
\hline Involvement & 3.16 & 1.15 & Moderate \\
Structure & 3.17 & 1.14 & Moderate \\
Reward & 2.98 & 1.51 & Moderate \\
Support & 3.25 & 1.12 & Moderate \\
$\begin{array}{l}\text { Opportunity for } \\
\text { advancement }\end{array}$ & 3.10 & 1.16 & Moderate \\
$\begin{array}{l}\text { Control } \\
\text { Total }\end{array}$ & 2.68 & 1.18 & Moderate \\
\hline \hline
\end{tabular}

Table 6 shows that the organization was at moderate level and mean at 3.06. All components were at moderate level including Support Structure Involvement Opportunity for Advancement, Reward and Control with the mean at 3.25, 3.17, 3.16, 3.10, 2.98 and 2.68 respectively.

TABLE 7. Mean and standard deviation of work engagement

\begin{tabular}{lrrl}
\hline \hline \multicolumn{2}{l}{ Work engagement $\mathbf{M}$} & S.D. & Level \\
\hline Vigor & 3.43 & 1.21 & High \\
Dedication & 3.48 & 1.12 & High \\
Absorption & 3.49 & 1.06 & High \\
Total & 3.47 & 1.13 & High \\
\hline \hline
\end{tabular}

Table 7 shows that the work engagement was at high level with mean at 3.47. All components were at high level including absorption, dedication and vigor with mean at $3.49,3.48$ and 3.43 respectively. Table 8 shows that the service quality was at high level with mean at 3.47. All components were at high level including assurance, responsiveness, empathy, reliability and tangibility with mean at 3.59, 3.56, 3.48, 3.46 and 3.41 respectively. The analysis of regression between positive psychological capital and organizational climate on service quality, the mediation role of work engagement of hotel service employees in Ratchaburi Province found a regression H0 =Positive psychological capital does not have a positive influence on the service quality and the mediation role of work engagement

H1 = Positive psychological capital has a positive influence on the service quality and the mediation role of coefficient between 22 and 89 . This shows that independent variables were independently studied. So, the hypothesis explained the selection of variables of positive psychological capital and organizational climate on service quality, the mediation role of work engagement of hotel service employees in Ratchaburi Province.

TABLE 8. Mean and standard deviation of service quality

\begin{tabular}{lccl}
\hline \multicolumn{1}{c}{ Service quality } & M & S.D. & Level \\
\hline Tangibility & 3.41 & 1.11 & High \\
Reliability & 3.46 & 1.12 & High \\
Responsiveness & 3.56 & 1.07 & High \\
Assurance & 3.59 & 1.06 & High \\
Empathy & 3.48 & 1.04 & High \\
Total & 3.50 & 1.08 & High \\
\hline \hline
\end{tabular}

\section{Hypothesis}

Hypothesis 1: Positive psychological capital has a positive influence on the service quality

HO $=$ positive psychological capital does not have a positive influence on the service quality

H1 = positive psychological capital has a positive influence on the service quality

The result shows that positive psychological capital has a relationship with service quality at high level by $\mathrm{R}$ of.81 and R Square of .63. Hope dimension has $t=4.31$, sig at 0.05 , Beta $=0.36$. This accepts the H1 in hope dimension. Optimism dimension has $\mathrm{t}=3.47$, sig at 0.05 , beta $=0.29$. This accepts the $\mathrm{H} 1$ in Optimism dimension. In conclusion, the hypothesis 1 was accepted in hope and optimism dimensions.

Hypothesis 2: Positive psychological capital has a positive influence on the service quality and the mediation role of work engagement

work engagement The positive psychological capital has a positive influence on the service quality and the mediation role of work engagement by using the mediation analysis (Baron \& Kenny, 1986; Judd \& Kenny, 1981). 
TABLE 8: The coefficient of positive psychological capital has a positive influence on the service quality the mediation role of work engagement

\begin{tabular}{cccccccc}
\hline \hline Model & $\begin{array}{c}\text { Independent } \\
\text { variable }\end{array}$ & $\begin{array}{c}\text { Dependent } \\
\text { variable }\end{array}$ & t. & sig. & Beta & R Square & $\mathrm{R}^{2}$ \\
\hline$(1)$ & $\begin{array}{c}\text { Positive } \\
\text { psychological } \\
\text { capital }\end{array}$ & $\begin{array}{c}\text { Service } \\
\text { quality }\end{array}$ & 20.062 & $0.000^{*}$ & 0.807 & 0.652 & $65.00 \%$ \\
& $\begin{array}{c}\text { Positive } \\
\text { psychological } \\
\text { capital } \\
\text { Work }\end{array}$ & $\begin{array}{c}\text { Work } \\
\text { engagement }\end{array}$ & 21.206 & $0.000^{*}$ & 0.823 & 0.677 & $67.50 \%$ \\
& $\begin{array}{c}\text { Service } \\
\text { quality }\end{array}$ & 26.445 & $0.000^{*}$ & 0.875 & 0.765 & $76.40 \%$ \\
\hline \hline
\end{tabular}

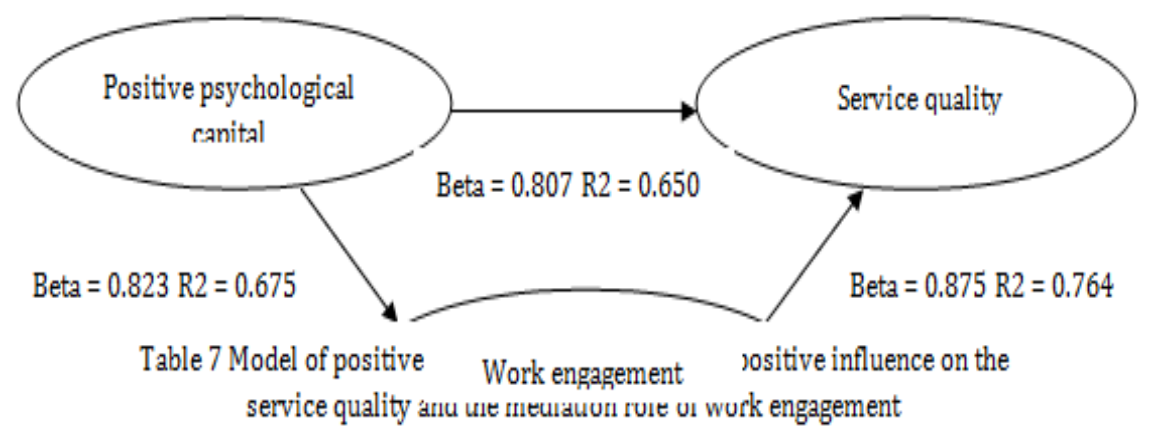

FIGURE 2. Model of positive psychology work engagement

TABLE 9: The coefficient of organization climate has a positive influence on the service quality the mediation role of work engagement

\begin{tabular}{|c|c|c|c|c|c|c|c|}
\hline Model & $\begin{array}{c}\text { Independent } \\
\text { variable }\end{array}$ & $\begin{array}{l}\text { Dependent } \\
\text { variable }\end{array}$ & t. & sig. & Beta & R Square & $\mathrm{R}^{2}$ \\
\hline (1) & $\begin{array}{l}\text { Organization } \\
\text { climate }\end{array}$ & $\begin{array}{l}\text { Service } \\
\text { quality }\end{array}$ & 17.685 & $0.000^{*}$ & 0.770 & 0.593 & $59.10 \%$ \\
\hline (2) & $\begin{array}{l}\text { Organization } \\
\text { climate }\end{array}$ & $\begin{array}{c}\text { Work } \\
\text { engagement }\end{array}$ & 16.801 & $0.000^{*}$ & 0.753 & 0.568 & $56.60 \%$ \\
\hline (3) & $\begin{array}{c}\text { Work } \\
\text { engagement }\end{array}$ & $\begin{array}{l}\text { Service } \\
\text { quality }\end{array}$ & 26.445 & $0.000^{*}$ & 0.875 & 0.765 & $76.40 \%$ \\
\hline
\end{tabular}

From the table 7, it can explain into 3 models. First model, the positive psychological capital affected the service quality at 0.65 and $t=20.06$, sig at 0.05 and beta $=0.81$. Second model, the positive psychological capital affected work engagement at 0.68 and $t=21.21$, sig at 0.05 and beta $=0.82$. Third model, the work engagement affected service quality at 0.77 and $\mathrm{t}=26.45$, sig at 0.05 and beta $=$ 0.88 . This revealed that the positive psychological capital has a positive influence on the service quality and the mediation role of work engagement. The positive psychological capital has directly affected the service quality and the mediation role of work engagement by coefficient at 0.81 . And, the positive psychological capital has a positive influence indirectly on the service quality and the mediation role of work engagement by coefficient at 0.72 and sig at 0.05 . In conclusion, the hypothesis 2 was accepted that positive psychological capital has a positive influence on the service quality and the mediation role of work engagement with significance at 0.05 .

Hypothesis 3: Organizational climate has a positive influence on the service quality

$\mathbf{H O}=$ Organizational climate does not have a positive influence on the service quality 
H1 = Organizational climate has a positive influence on the service quality

The result shows that the relationship between organizational climate and service quality is at high level by $\mathrm{R}=0.84$ and $\mathrm{R}$ square $=0.71$. Involvement dimension was at $\mathrm{t}=2.09$, sig at 0.05 and beta $=0.13$. So, the $\mathrm{H} 1$ was accepted in hope and involvement dimensions.

Structure dimension was at $\mathrm{t}=5.698$, Sig. $=0.000<0.05$ and Beta $=0.388$. So, the $\mathrm{H} 1$ was accepted in hope and structure dimensions. Support dimension was at $t=7.629$, Sig. $=0.000<0.05$ and Beta $=0.504$. So, the $\mathrm{H} 1$ was accepted in hope and support dimensions. In conclusion, the hypothesis 3 was accepted in the support dimension, structure dimension and involvement dimension that have a positive influence on the service quality.

Hypothesis 4: Organizational climate has a positive influence on the service quality and the mediation role of work engagement

$\mathbf{H O}=$ Organizational climate does not have a positive influence on the service quality and the mediation role of work engagement

H1 = Organizational climate has a positive influence on the service quality and the mediation role of work engagement
The Organizational climate has a positive influence on the service quality and the mediation role of work engagement by using the mediation analysis (Baron \& Kenny, 1986; Judd \& Kenny, 1981). From the table 8, it can explain into 3 models. First model, the organizational climate affected the service quality at 0.59 and $t=17.68$, sig at 0.05 and beta $=$ 0.77. Second model, the organizational climate affected work engagement at 0.57 and $t=16.80$, sig at 0.05 and beta $=0.75$. Third model, the work engagement affected service quality at 0.77 and $t=26.45$, sig at 0.05 and beta $=$ 0.88 . This reveals that the organizational climate has a positive influence on the service quality and the mediation role of work engagement. The organizational climate has directly affected the service quality and the mediation role of work engagement by coefficient at 0.77 . And, the organizational climate has a positive influence indirectly on the service quality and the mediation role of work engagement by coefficient at 0.66 and sig at 0.05 . In conclusion, the hypothesis 4 was accepted that the organizational climate has a positive influence on the service quality and the mediation role of work engagement being significant at 0.05 .

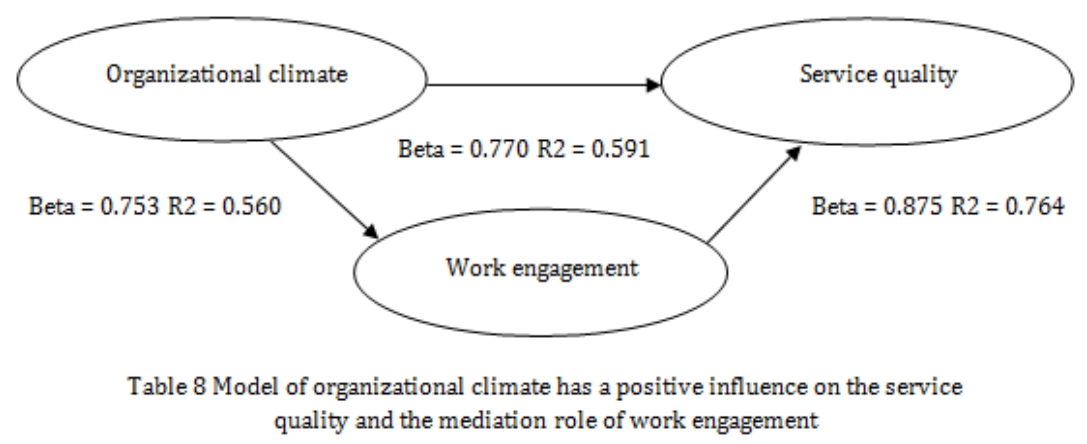

FIGURE 3. Model of positive effect of organizational climate on service quality

\section{Qualitative Research}

The qualitative research was conducted by focus group interview with 10 hotel service employees who had received an excellent service quality award in the past 2 years. The focus group discussion took 2.5 hours. All of the 10 hotel service employees had received an excellent service quality award in the past 2 years. This showed that all of 10 hotel service employees had good performance. Therefore, I can conclude that hotel service employees have a work engagement because of their positive perception in the organization, organizational climate, and supportive behavior from their coworkers and bosses. These are some sentences that will show that employees have work engagement:

"I think that those working at the hotel need to have good attitudes because this job is about the service with the guest who come from the different parts of the world, have different wants and needs. So we need good attitudes to handle the different guests. If we have good attitudes, it leads to good outcome"

"I love this hotel because of the owner. Many years ago, one day I talked with my husband via mobile phone that 
we have a money problem. After I finished talking with my husband few minutes later the owner came to me and put the money into my hand. That moment I didn't have a word at all but I felt so touched. Later, I promised to myself that I will work with her (owner) until I can't work anymore."

"For me, I come to work here because of my friend. He's also working here and has same position. So when I have a problem in working place I feel like it will be all right because he will help me. This is not only because of him but other workmates also. We will help each other when someone has to face the problem in the working place. So, when I am working I will do everything I can to help my workmates"

"The boss is also important for me. In the working place there is often some problem I cannot fix by myself, I need some help from the boss. Working as receptionist for 24 hours makes it difficult to contact the boss all the time. But, for my boss, I can contact anytime when I have a problem so I feel safe at the working place and I think this also helps me to do a good performance because I can consult the boss anytime."

The result from the focus group interviews revealed that hotel service employees have high level of work engagement. They explained that they feel a lot of energy to come to the hotel for working as hotel service employees. They also have good attitudes at work that leads to good outcomes. Some of 10 hotel service employees were proud to be a hotel service employee; they loved to serve the guests. Below is the example sentence to show the high level of work engagement:

"I feel good every morning to come to work especially when the hotel has many events or conferences."

"To be honest, I feel very excited to come to work at the hotel. Last week, I was very excited because the hotel had1 event and 3 meetings so it was going to be busy. So I woke up early in the morning with a lot of energy and also prepared myself to serve the guests"

"I have been working as hotel service employee when I was 20 years old and now I'm 45 years. I think I love this job. If I do not I might go to work for anything else"

"In my opinion, working as the hotel service employee is not easy but is not difficult as well. And, you need a good attitude to do the good action."

These are sentences from the focus group interviews with 10 hotel service employees. This shows that hotel service employees have high level of work engagement. They have vigor, dedication and absorption dimensions.
Work engagement is defined as positive behavior or a positive state of mind at work that leads to good outcomes. Work engagement is an important construct of happiness and well-being at work and has been strongly associated with employee turnover (Schaufeli \& Bakker, 2004:293315).

\section{DISCUSSION AND CONCLUSION}

The study of the effect of positive psychological capital and organizational climate on service quality and the mediation role of work engagement of hotel service employees in Ratchaburi Province found that most of the hotel service employees were females. So it's shown that females were more interested in working at the hotel than males and most of them were single. The range of experience was between 1-3 years of working. Hotel service employees were at moderate level of positive psychological capital, organizational climate, work engagement and service quality. It's shown that hotel service employees should have a chance to develop themselves in all factors such as increasing positive psychological capital etc. When hotel service employees have high positive psychological capital they can have "self-efficacy" that can go through the problems because they have confidence to fix the problem by themselves or a "hope" that they would get better in the next day after they face the problems. Optimism is also helpful to help hotel service employees to look at only the good side and do only the good thing. Organizational climate is one factor that could affect the service quality of hotel service employees. Work engagement is an important construct of happiness and well-being at work and has been strongly associated with employee turnover (Schaufeli \& Bakker, 2004:293-315).

\section{RECOMMENDATIONS}

This study recommends observing further the work engagement of employees from different job functions in order to improve service quality for entire organization.

\section{ACKNOWLEDGEMENTS}

This conference was funded by the Graduate School of Srinakharinwirot University. The author would like to thank the Srinakharinwirot University, Dr. Sudarat Tuntivivat and Dr. Ujsara Prasertsin who supported the paper for this conference, and all hotel service employees who kindly participated in this study. 


\section{REFERENCES}

Albanese, R. 1981. Managing: Toward accountability for performance. Homewood, IL: Regal Books.

Baron, R.M., \& Kenny, D.A. 1986). The moderator-mediator variable distinction in social psychological research: Conceptual, strategic, and statistical considerations. Journal of Personality and Social Psychology, 51(6): 11731182.

Berry, L.L., Zeithaml, V.A., \& Parasuraman, A. 1985. Quality counts in services, too. Business Horizons, 28(3): 44-52. DOI: 10.1016/0007-6813(85)90008-4

Bitner, M. 1992. Service scopes: The impact of physical surroundings on customers and employees. Journal of Marketing, 56 (2): 57-71.

Boonmak, S., Peeranut, S., \& Suchart, T. 2013. Strategic planning for Ratchaburi Province and the indicators. Stamford Journal, 5(1): 1-20.

Cronin Jr, J.J., \& Taylor, S.A. 1992. Measuring service quality: A reexamination and extension. The Journal of Marketing, 56(3): 55-68. DOI: 10.2307/1252296

Dubrin, A.J. 1984. Foundations of organizational behavior: An applied perspective. Englewood Cliffs, NJ: Prentice Hall.

Heung, V.C., \& Wong, M.Y. 1997. Hotel service quality in Hong Kong: A study of tourists' expectations. Journal of Vacation Marketing, 3(3): 264-271. DOI: 10.1177/135676679700300307

Jung, H.S., \& Yoon, H.H. 2015. The impact of employees' positive psychological capital on job satisfaction and organizational citizenship behaviors in the hotel. International Journal of Contemporary Hospitality Management, 27(6): 1135-1156. DOI: 10.1108/IJCHM-01-2014-0019

Judd, C.M., \& Kenny, D.A. 1981. Process analysis estimating mediation in treatment evaluations. Evaluation Review, 5(5): 602-619.

Karatepe, M.O., \& Demir, E. 2014. Linking core self-evaluations and work engagement to work-family facilitation: A study in the hotel industry. International Journal of Contemporary Hospitality Management, 26(2): 307-323. D0I: 10.1108/IJCHM-01-2013-0008

Karatepe, O.M., \& Karadas, G. 2015. Do psychological capital and work engagement foster frontline employees' satisfaction? A study in the hotel industry. International Journal of Contemporary Hospitality Management, 27(6): 1254-1278. DOI: 10.1108/IJCHM-01-2014-0028

Ling Suan, C., \& Mohd Nasurdin, A. 2016. Supervisor support and work engagement of hotel employees in Malaysia: Is it different for men and women? Gender in Management: An International Journal, 31(1): 2-18. D0I: 10.1108/GM11-2014-0105

Kahn, W.A. 1990. Psychological conditions of personal engagement and disengagement at work. Academy Of Management Journal, 33(4): 692-724.

Litwin, G.H. \& Stringer, R.A. 1968. Motivation and organization climate. Boston, MA: Harvard University Press.

Luthans, F., Youssef, M. \& Voloi, B. 2007. Psychological capital: Developing the humen competitive edge. Oxford, UK: Oxford University press.

Minh, N.H., Ha, N.T., Anh, P.C., \& Matsui, Y. 2015. Service quality and customer satisfaction: A case study of hotel industry in Vietnam. Asian Social Science, 11(10): 73-85.

Roderic, G. 2007. A Climate of success: Creating the right organization climate for high performance. New York, NY: Elsevier/Butterworth-Heinemann.

Saks, A.M. 2006. Antecedents and consequences of employee engagement. Journal of Managerial Psychology, 21(7): 600-619.

Schaufeli, W.B., \& Bakker, A.B. 2004. Job demands job resources and their relationship with burnout and engagement: A multi-sample study. Journal of Organizational Behavior, 25(3): 293-315. D0I: 10.1002/job.248

Snyder, C.R., \& Lopez, S.J. 2002. The handbook of positive psychology. New York, NY: Oxford University Press.

Taştan, S.B., \& Güçel, C. 2014. Explaining entrepreneurial behaviors of employees with perceived organizational climate and testing the mediating role of organizational identification: A research study among employees of Turkish innovative firms. Procedia-Social and Behavioral Sciences, 150: 862-871. 